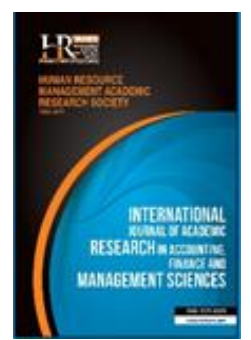

International Journal of Academic Research in Accounting, Finance and Management Sciences

Vol. 10, No.2, April 2020, pp. 195-199

E-ISSN: 2225-8329, P-ISSN: 2308-0337

(C) 2020 HRMARS

www.hrmars.com

To cite this article: Saddam, S. Z. (2020). The Motivation of Intellectual Capital on Firm's Financial Performance: Analysis on Financial Sector in Malaysia., International Journal of Academic Research in Accounting, Finance and Management Sciences 10 (2):195-199.

http://dx.doi.org/10.6007/IJARAFMS/v10-i2/7436

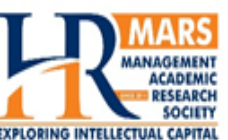

www.hrmars.com

ISSN: 2225-8329

\title{
The Motivation of Intellectual Capital on Firm's Financial Performance: Analysis on Financial Sector in Malaysia
}

\author{
Siti Zaitun Saddam \\ Faculty of Business Management, Universiti Teknologi MARA, Malaysia
}

\begin{abstract}
The intention of this experiential analysis is to explore the stimulus of intellectual capital (IC) on the financial performance of firms itemized in financial sector on Bursa Malaysia Berhad. Scholars regard intellectual capital as a market value creator. In the era of information technology, competitive advantage can only be found through intangible assets (intellectual capital). Nowadays, the factors of production have changed to information and knowledge. Therefore, the execution of Knowledge based Economy (K-economy) is necessary for an improved development and competitiveness. The Malaysian economy of today has changed from a Peconomy which stands for production economy to K-economy whereby the knowledge has been the main key driver. Today, in the k-economy, knowledge is known as one of the primary factors in sustaining economic growth apart from land, labour and physical capital. This study measure IC by the value-added Intellectual coefficient measurement model. Most of the scholars regards finance industry as a knowledge-based industry, thus this industry is encompassed. Hence, it generates it a perfect sector for study on intellectual capital. Knowledge based industries are considered as the strength of the new economy called knowledgebased economy. Economists believe financial sector has a major contribution in long term economic growth and development, also the important pillar for economy.
\end{abstract}

Key words

Intellectual Capital, Firms Financial Performance, Financial Sector, Intangible Asset, Knowledge-Based E, VAIC

Received: 10 Jun 2020 (C) The Authors 2020

Revised: 09 Jul 2020 Published by Human Resource Management Academic Research Society (www.hrmars.com)

Accepted: $22 \mathrm{Jul} 2020 \quad$ This article is published under the Creative Commons Attribution (CC BY 4.0) license. Anyone may reproduce, distribute, translate and create derivative works of this article (for both commercial and

Published Online: 03 Aug 2020 non-commercial purposes), subject to full attribution to the original publication and authors. The full terms of this license may be seen at: http://creativecommons.org/licences/by/4.0/legalcode

\section{Introduction}

Company's financial performance mainly mirrors the overall progress and financial well-being of business sector over quantified period. According to Naz \& ljaz (2016) it shows the achievement organization will have the option to totally utilize its assets to gain by investors' wealth and profitability. Pantea et al. (2014) specified, there are various models have been used in analyzing firm performance and the core function of the analyzed model is to expand business operational competence over improved decision-making process. Fundamentally, Naz \& ljaz (2016) detailed, the most common measurement of company performance in the ground of finance is financial ratios. Generally, organization's financial performance is the principle worry for the depositors and leasers, since it conveys data scheduled an organization's monetary circumstances for both the security and productivity of the investor's investment. Financial performance has a superior influence towards growing prospects also achievement and failure of business, because it is significance in all economic conclusion.

Edvinsson \& Malone (1997) classified firm resources via Skandia Navigator. The resources can be separated into 2 groups' specifically financial capital and intellectual capital, financial capital mainly 
comprises of money or near money, it is tangible in nature and intellectual capital is intangible such as goodwill, patents and copyright. This is situation is closely linked into resource-based theory, this theory explains the resources that endure in a firm can be cracked down into two group includes, intangible and tangible resources. Therefore, firms possess a package of resources which are tangible and intangible to support in attaining competitive advantage. All these resources are associated in creating worth and expand firms' financial performance. The resource-based theory claimed, assets give an amazing possibility to the firm to accomplish upper hand over its rivals (Adnan \& Sohail, 2018). Additionally, it examines the connection between company's inner attributes and competitive advantage. Thus, this is an ideal hypothesis to concentrate on company performance (Cruz and Haugan, 2019).

Edvinsson \& Malone (1997), includes financial capital as a company's total capital. Financial capital comprise of physical assets like plant and machinery, strategic manufacturing location, and financial assets which contain the firms' ability, elevation of equity, firms' borrowing capacity, which are used for companies and organizations to generate value (Dess et al., 2009). In finance, this asset is referred as capital structure, this capital will directly affect the firm performance (Ramli et al., 2019).Capital structure theory has been a confusing issue in corporate finance and accounting literature, this happen considering the pivotal theory of Modigliani and Miller (1958) the right amount amongst equity and debt can deliver perfect capital structure. The ideal capital structure expands profits and investors' worth. Though, there is not at all understanding between scholastics on what is perfect capital structure (Addae et al., 2013) the investigation for the ideal capital structure has instructed into hypotheses, such as, the trade-off and pecking order.

Apart from resources, Skandia navigator which comprised a holistic view on performance measurement mentioned on intellectual capital as a market value creator. Intellectual capital is a concept which is close to intangible assets and it plays a key role in wealth creation for companies (Edvinsson \& Malone 1997; Manzari et al., 2012). The association among company performance and intangible assets is truly on alluring subject, explicitly in the midst of serious monetary disarray, likewise at whatever point organizations are seeing for new goals so as to suffer and advance in business (Sumedrea, 2013). Nowadays, business organisation is fighting to endure, this is mainly due to the nature of businesses today which depends on intangible resources also the competitive business arena (Gogan, 2014).

Saunders \& Brynjolfsson (2016) believed, in the current period of K-economy, the world is looking with two recent influences of creation to be specific knowledge and information Therefore, the execution of k-economy is compulsory for improved development and competitiveness. Therefore, to remain in this situation, K-economy endures a great solution for the revolution against industrial to knowledge-based humanity.

Consequently, Malaysia has announced Knowledge Economy in 2001 so as to support with the new worldwide economy and to accomplish viable financial development through endeavour on intellectual capital (Cavusoglu, 2016).The proliferation of a new type of the knowledge economy is one of the most significant changes that can be observed in the modern world. Therefore, in this condition, intellectual capital is recognised as a support of firms' gain and innovation. Whereby, competitive advantage can be perceived as the centre drivers of nations and firms' future advancement just as people's improvement at that point in the long run influence the entire economy (Buallay, 2017; Luv, 2004).

According to Carayannis et al. (2018), the position of knowledge in generating value added, driving efficiency and empowering financial development has for some time been recognize. Related this affirmation of the focal job of information, in the present economies has been an extra spotlight on knowledge. Though, in the traditional economy, knowledge was not neither figured outlook the important spring and propulsive intensity of financial development and the increasing of the standard of life. Yet, in current situation of twentieth century, the social order start to mindful of the noteworthy. These days, the knowledge has built up a vital piece of financial philosophies and models. Serrat (2017) claimed K-based economy is stranded on a philosophy that concentration on intangible asset as a major motivator.

Analysis of this study is spread over across finance industry firms listed on the bursa Malaysia, the main idea of exploring on finance industry is because of countries economy and growth highly dependent on monetary and financial stability, thus finance industry shows a crucial part in the expansion of financial system. Therefore, once the financial sector is further advanced, then added financial assets capable to 
assigned towards creative real investment and additional physical capital gets moulded. Zarrouk et al., (2017) specified this situation will empower financial turn of events. A Good financial system will ensure effective and efficient financial intermediation, economic growth contribution and development. Additionally, finance industry is knowledge intensive industry therefore, it is a perfect industry consideration studies on intellectual capital (Al-Musali \& ku Ismail, 2014; Cabrita et al., 2017; Goh, 2005).

\section{Literature review}

The advantages of knowledge in the current time perceived for value creation. Knowing the need of changing from input-driven economy to a knowledge driven economy to endure economic development, Malaysia introduced k-economy in 2001 by announcing Knowledge Economy Master Plan. The introduction of the idea designated the evolution of Malaysian economy into knowledge economy. The plan contains of policies to encourage the expansion of knowledge economy. The Organisation for Economic Co-operation and Development (OECD, 1996) define a knowledge economy as an economy in which the creation, appropriation as well as utilization of information as key controller of advancement. The association accepted that, in this economy the creation, dispersion and utilization of information is the primary handler of development, prosperity formation and work over all businesses. Besides, this isn't just restricted to those enterprises that has been arrange as high innovation or knowledge intensive division.

Recently, the global economy is experiencing an organizational change in which the economic growth is closely linked to knowledge-based industries. Therefore, nations that exceed expectations in knowledge will be the financial pioneers of things to come. In addition, those dependent on assembling, agribusiness and the fare of items will fight to make development and high-value jobs. The current advancement pioneers are the US, the UK, Sweden, Switzerland and Singapore, admit to the World Intellectual Property (IP) Organisation's Global Innovation Index. Thus, Malaysia has been stimulated to develop the knowledge sector as a key growth for the economy. The era of knowledge economy has positioned knowledge elected the greatest vital factor for national, regional and local economic growth (Lonnqvist et al., 2014).

Firms working in the knowledge economy be unexpected extra on intellectual capital as opposed to physical capital for development (Goh, 2005). Physical capital indicates to the traditional factor of production such as land, labor, and capital and entrepreneur; whereas intellectual capital refers to knowledge, creativity, skill and corporate culture (Goh, 2005). The importance on emerging knowledge economies is determined by the belief that knowledge has substituted the old production factors including Land, labour, capital and entrepreneur in economic development and production (Drucker, 1993).

Since the K-economy arise and develops the leading method of business, firms have been depending more on the intellectual capital in order to attain competitive advantage and advancement potential (Sveiby, 1997; Hamel \& Prahalad, 1996; Lev, 2001). Additionally, the development of a firm's intellectual capital has been understood as an initial gauge for succeeding performance (Roos \& Roos, 1997).

Concerning the valuation model, Intellectual capital has been estimated with a few models. Every valuation model has a few points of interest and detriments (Sydler, Haefliger and Pruksa, 2014). This study is using Valued Added intellectual Capital Model (VAIC). The VAIC model has some advantages over other valuation models. Nimtrakoon (2015) had listed five advantages. Firstly, in characterizing the intellectual capital the model is uncomplicated and easy to utilize. Second, the data is easy to gain and possible as entirely the information is accessed from annual reports (secondary data). Third, all the information is accomplished from inspected budget summaries, subsequently, the estimation is unbiassed and provable (Goh, 2005). Fourth, the model composes cross-authoritative or cross-national examination plausible, differentiating other estimation models which include both money related and non-budgetary measures as typically including some close to home decisions. Fifth, it is gainful as the firm can rehearse the model to appraise their own scholarly capital and firms' performance (Fang \& Fang, 2009; Laing et al., 2010).

The relationship between intellectual capital and financial performance is illuminated by the Resource-based view hypothesis and that examination additionally acknowledges a similar hypothesis. The resource-based theory (RBV) evaluates companies' assets as the noteworthy factor in accomplishing seriousness and firm execution. Firm assets consolidate all benefits, abilities, authoritative procedures, firm qualities, data, information that are estimated through a firm that permit to plan and creation systems in 
which progress its proficiency and viability (Daft, 1992). The assets can be an establishment of upper hand for a firm in arranging and actualizing a value creation.

Though, methodically Barney (1991) specified, in order to have the ability achieve to competitive advantage, the firm's resources enforced to have four characteristics namely; valuable, rare, inimitable and non-substitutable (VRIN). Valuable is the capability of companies' assets to make maintainable profit. Secondly, resources are thought to be rare when the resources are heterogeneously disseminated over firms, not simply reachable to rivals and controlled by very limited firms. Inimitable resources mean the resources of the firm capable in defending from being duplicated from opponents. Lastly, non-substitutable resources are resources with no comparable planned resources or capabilities.

Moreover, Belkaoui (2003) claimed that resources of a firm can be divided into two groups specifically tangible and intangible resources. According to Barney (1991), tangible resources include physical skill used in a firm, a firm's plant and equipment, its geographic location and its access to raw material. On the other hand, intangible resources refer to human capital and organizations capital. Human capital assets include the preparation, experience, judgment, knowledge, connections and understanding of individual administrators and laborers in a firm.

\section{Conclusions}

Conclusively, the importance of Intellectual Capital has been widely contributed to firms' growth prospects and performance. However, the financial statements resulting from real accounting standards don't convey to the directors the basic data required. Because, the standard financial information does not include the intangible asset, this cans consequence to erroneous decision making. So, it is hard to forecast or gauge the company's upcoming financial performance, and its profit generating aspects. Thus, firms are exposed to losing risk appreciated competitive advantage. Nowadays, with the speedy change toward knowledge economy, the important of value creation and competitiveness solely dependent on intangible assets. Due to that reason, knowledge-based economy has been implemented for economic growth and sustain competitive advantage rather than focusing on traditional factor of production.

\section{References}

1. Addae, A. A., Nyarko-Baasi, M., and Hughes, D. (2013). The effects of capital structure on profitability of listed firms in Ghana. European Journal of Business and Management, 5(31), 215-229.

2. Adnan, M., Abdulhamid, T., \& Sohail, B. (2018). Predicting Firm Performance through Resource Based Framework. European Journal of Business and Management, 10(1).

3. Al-Musali, M. A., \& Ku Ismail, K. N. I. (2016). Cross-country comparison of intellectual capital performance and its impact on financial performance of commercial banks in GCC countries. International Journal of Islamic and Middle Eastern Finance and Management, 9(4), 512-531.

4. Barney, J. (1991). Firm resources and sustained competitive advantage. Journal of Management, 17(1), 99-120.

5. Belkaoui, A. (2003). Intellectual Capital and Firm Performance of US Multinational Firms: A Study of The Resource-Based And Stakeholder Views. Journal of Intellectual Capital, 4(2), 215-226.

6. Buallay, A., Cummings, R., \& Hamdan, A. (2019). Intellectual capital efficiency and bank's performance. Pacific Accounting Review.

7. Cabrita, M. R., \& Silva, M., Rodrigues, A., \& Duenas, M. (2017). Competitiveness and disclosure of intellectual capital: an empirical research in Portuguese banks. Journal of Intellectual Capital.

8. Carayannis, E. G., Ferreira, J. J. M., Jalali, M. S., \& Ferreira, F. A. F. (2018). MCDA in knowledgebased economies: Methodological developments and real world applications. Technological Forecasting and Social Change, 131, 1-3.

9. Cavusoglu, B. (2016). Knowledge Economy and North Cyprus. Procedia Economics and Finance, 39, 720-724.

10.Cruz, A. M., \& Haugan, G. L. (2019). Determinants of maintenance performance: A resource-based view and agency theory approach. Journal of Engineering and Technology Management, 51, 33-47.

11.Daft, R. L. (1992). Organizational theory and Design, New York: West Publishing Company. 
12.Dess, G. G., Lumkin, T. G., Eisner, B. A., \& McNamara, G. (2009). Strategic Management: Text and Cases 7TH Global Edition. New York: McGraw-Hill.

13.Drucker, P. (1993), Post-Capitalist Society, Butterworth-Heinemann Ltd, Oxford.

14.Edvinsson, L. and Malone, M.S. (1997). Intellectual Capital: Realizing your Company's True Value by Finding Its Hidden Brainpower. Harper Collins Publishers, New York, NY.

15.Goh, P. K. (2005). Intellectual capital performance of commercial banks in Malaysia.

16.Journal of Intellectual Capital, 6(3), 385-396.

17.Hamel, G., \& Prahaland, C. K. (1996). Competing in the new economy: Managing out of bonds. Strategic Management Journal, 17: 238.

18.Laing, G., Dunn, J., and Hughes-Lucas, S. (2010). Applying the VAIC model to Australian hotels. Journal of Intellectual Capital, 11(3), 269-283.

19.Lonnqvist, A., Kapyla, J., Salonius, H., and Yigitcanlar, T. (2014), "Knowledge that matters", European Planning Studies, Vol. 22 No. 10, pp. 2011-2029.

20.Modigliani, F., and Miller, M. H. (1958). The cost of capital, corporate finance and theory of investment. America Economic Review, 48, 261 -97.

21.Naz, F., \& ljaz, F. (2016). Financial Performance of Firms: Evidence from Pakistan Cement Industry. Journal of Teaching and Education.

22.Nimtrakoon, S. (2015). The relationship between intellectual capital, firms' market value and financial performance: Empirical evidence from the Asean. Journal of Intellectual Capital, 16(3), 587-618.

23.OECD. (1996). The Knowledge-based Economy, Organisation for Economic Cooperation and Development (OECD), Paris.

24.Pantea, M., Gligor, D., \& Anis, C. (2014). Economic Determinants of Romanian Firms' Financial Performance. Procedia - Social and Behavioral Sciences, 124, 272-281.

25.Ramli, N. A., \& Latan, H., \& Solovida, G. (2018). Determinants of Capital Structure and Firm Financial Performance - A PLS-SEM Approach: Evidence from Malaysia and Indonesia. The Quarterly Review of Economics and Finance.

26.Roos, G., and Roos, J. (1997). Measuring your company's intellectual performance.

Long Range Planning, 30(3), 413-426.

27.Serrat, O. (2017). A Primer on Intellectual Capital. 197-20.

28.Stewart, T., \& Ruckdeschel, C. (1997). Intellectual capital: The new wealth of organizations. New York, NY.

29.Sumedrea, S. (2013). Intellectual Capital and Firm Performance: A Dynamic Relationship in Crisis Time. Procedia Economics and Finance, 6, 137-144.

30.Sveiby, K. E. (1997). The New Organisational Wealth - Managing and Measuring Knowledge-based Assets, Berrett-Koehler, San Francisco, CA.

31.Sydler, R., Haeflinger, S., and Pruksa, R. (2014). Measuring intellectual capital with financial figures: can we predict firm profitability. European Management Journal, 32(2), 244-259.

32.Yigitcanlar, T. (2014), "Empirical approaches in knowledge city research", Expert Systems with Applications, Vol. 41 No. 12, pp. 5547-5548.

33.Young, C.-S., Su, H.-Y., Fang, S.-C., \& Fang, S.-R. (2009). Cross-country comparison of intellectual capital performance of commercial banks in Asian economies. The Service Industries Journal, 29(11), 15651579.

34.Zarrouk, H., \& Ghak, T., \& Haija, E. (2017). Financial development, Islamic finance and economic growth: evidence of the UAE. Journal of Islamic Accounting and Business Research. 8. 2-22. 